Lamb, T.E. (2017) 'Knowledge about language and learner autonomy', in Cenoz, J., \& Gorter, D. (Eds.) (2017) Language Awareness and Multilingualism. ISBN 978-3-319-02239-0. In: Encyclopedia of Language and Education. Cham, Switzerland: Springer International Publishing Switzerland: 173-186

\title{
Knowledge about language and learner autonomy
}

\author{
Terry Lamb, University of Sheffield
}

\begin{abstract}
The chapter traces the development of the construct of autonomy in language learning, including its relationship with aspects of knowledge about language, since the 1970s. It distinguishes between two broad theoretical orientations: one which focuses on learning systems in which learners take decisions about the content and processes of their learning; and one which focuses on the cognitive and metacognitive capacities which enable learners to take responsibility for their learning. It also identifies key theoretical and thematic shifts and their implications for research and practice. Recognition that learner autonomy rarely involves learners learning in isolation led to its exploration via sociocultural frameworks, as a dynamic, situated construct, which is operationalised in multifarious ways. Although early developments in the field began in self-access learning, this quickly shifted to research and practice in classroom contexts, introducing a new focus on the teacher and the construct of teacher autonomy. Development of pedagogy for autonomy included critical perspectives on learner and teacher autonomy, related to notions of external and internal constraints (including learner and teacher beliefs), power relationships, and (languages) education as empowerment and transformation. The chapter also shows how autonomy has been explored in relation to other constructs, such as motivation and identity, and in the context of rapid technological development, whilst acknowledging the various challenges to its operationalization. Finally, it argues that future developments in the field must engage with the increasing complexity of the $21^{\text {st }}$ century globalised world, by building on new interdisciplinary, ecological and spatial approaches to research and practice.
\end{abstract}

\section{Introduction}

The development of the construct of autonomy from its original political meaning (the emergence of the self-governing city state) to a personal one (an independent, free-thinking individual) has been attributed to Plato (Marshall, 1996). It has since moved through the rationalist interpretation of Kant (an individual able to govern him/herself according to reason and independently of any emotions or preferences) to postmodern or critical versions, which deny the possibility of divorcing the individual from the dynamic socio-political context and the power it exerts over him/her (Zembilas and Lamb, 2008). Such philosophical shifts have inevitably influenced the ways in which understandings of the nature of education construe the individual learner, encompassing the Kantian rationalist interpretations that involve acquisition of knowledge and 
informed choice (e.g. Hirst), the romantic, freedom-oriented approaches of Rousseau, and the critical pedagogies of, for example, Freire and Giroux.

Learner autonomy as a construct is consequently challenging to define, as it manifests itself in different ways largely dependent on the context (spatial, cultural, temporal etc) in which it is being exercised. Since the late 1970s, there has been a particular surge in research across the world in the field of learner autonomy in language learning, reflecting the ideological, political, social and pedagogical shifts that have characterised recent decades (see Benson (2011) for a comprehensive overview of the field). This chapter will trace the development of this research, capturing its diversity and identifying the trends of the past and present as well as possible future directions.

\section{Early developments}

The phenomenon of learner autonomy has to be located in the wider frameworks of general learning theory as well as theories of first and second language acquisition and language learning and teaching. These relate to the ways in which learning is understood to occur generally and also in relation to the specificities of language learning, and to carry implications for the roles of the learner and the teacher as well as the nature of knowledge about language. For example, behaviourist approaches tend to involve more external direction and less learner choice, e.g. the audio-visual approach, whereas constructivist approaches imply a more active role for the learner, who engages in knowledge construction within a socio-cultural context, e.g. task-based learning. In relation to knowledge about language, there appears to be consensus that instruction needs to focus on the development of both implicit and explicit knowledge, though to differing degrees. Implicit knowledge, as procedural knowledge, is readily available for communication and is developed through communicative activities. There is general agreement that such activities are crucial for language learning, but the extent to which explicit knowledge should be developed, "that is, declarative knowledge of the phonological, lexical, grammatical, pragmatic and socio-cultural features of language" (Ellis, 2004: 244), as well as how it should be developed, is more contentious, as it is less easily activated. Related to this are discussions about the balance between a focus on meaning and a focus on form. For Schmidt (1994), learning requires conscious attention to form, which, for him, means noticing linguistic features rather than awareness of grammar rules. Early research into the characteristics of a "good language learner" suggested that attention to both form and meaning, but also to language learning strategies, is characteristic of language learning success (e.g. Naiman et al., 1978). It is worth mentioning the development of the language awareness movement in Europe, which was concerned with the development of "sensitivity to and conscious awareness of the nature of language and its role in human life" (Donmall, 1985: 7), engaging learners in learning not only about linguistic patterns and approaches to language learning but also sociolinguistic issues intended to encourage the appreciation of linguistic diversity and interlingualism. Despite the lack of consensus over definitions of learner autonomy, both awareness and reflection are features, which have appeared throughout the literature on learner autonomy since the 1970s. 
According to Jiménez Raya and Lamb (2008: 64), close reading of the literature on learner autonomy suggests two main orientations:

- Manifestations that focus on external factors that facilitate the learner taking responsibility for different aspects of the learning process such as planning, implementation and evaluation of learning and learning decisions (flexible learning, project work...), and

- those that centre on internal factors that predispose learners toward accepting responsibility and controlling one's thoughts and actions as a learner (learning to learn, self-regulated learning, strategy training).

The first orientation, which Jiménez Raya and Lamb refer to as "independent learning", focuses on self-management and is exemplified in the earliest definition of autonomy, by Holec (1981: 3), then Director of the Centre de Recherches et d'Applications en Langues (CRAPEL) at the University of Nancy, France:

To take charge of one's own learning is to have, and to hold, the responsibility for all the decisions concerning all aspects of this learning, i.e.:

- - determining the objectives;

- - defining the contents and progressions;

- - selecting methods and techniques to be used;

- - monitoring the procedure of acquisition properly speaking (rhythm, time, place, etc.)

- - evaluating what has been acquired.

The autonomous learner is himself capable of making all these decisions concerning the learning with which he is or wishes to be involved.

This defines a system, in which learners are able to make decisions throughout the language learning process, and which emerged from CRAPEL's context of self-access learning. The second orientation, which Jiménez Raya and Lamb call "autonomous learning", emerges from general work in cognitive psychology and reflects a form of learner self- awareness and self- regulation, which engages with developments in the field of motivation (e.g. Ushioda, 1996), learning strategies, both cognitive and metacognitive (e.g. Macaro, 2001) as well as metacognitive knowledge and beliefs (e.g. Wenden, 1999). These cognitive and psychological elements enable learners to take responsibility for and control over their learning. They are suggested in Little's (1991) definition:

"Essentially, autonomy is a capacity - for detachment, critical reflection, decision-making, and independent action. It presupposes, but also entails, that the learner will develop a particular kind of psychological relation to the process and content of his learning. The capacity for autonomy will be displayed both in the way the learner learns and in the way he or she transfers what has been learned to wider contexts." (Little, 1991: 4)

Although both of these manifestations of learner autonomy reflect rationalist traditions, they offer two different, but complementary, understandings of the construct of learner autonomy. 


\section{Major contributions}

The chapter will now consider the ways in which the field of learner autonomy has developed since its early days, paying attention to key theoretical and thematic shifts. On a theoretical level, Benson (1997) suggested that there are three versions of learner autonomy: technical autonomy, which refers to the learner's technical ability to learn by him/herself in terms of strategies, techniques and skills; psychological autonomy, which suggests that it is "a capacity - a construct of attitudes and abilities - which allows learners to take more responsibility for their own learning" (ibid: 19), and which therefore includes engagement on an affective level; and political autonomy, whereby learners have "control over the processes and content of learning", meaning that they have the opportunity to define their own goals and to have a 'voice', thereby reinforcing the links between autonomy and agency.

The Council of Europe has made a major contribution to development in the field of learner autonomy in language learning, having introduced the construct through their Modern Languages Project, which began in 1971 and which led to the establishment of CRAPEL. The Council's understanding of the significance of learner autonomy was later reflected in the development of the Common European Framework of Reference for Languages (CEFR) (Council of Europe, 2001), intended to develop a common understanding of L2 proficiency. The teaching methods proposed by the CEFR are explicitly intended to promote learner autonomy, stating the importance of "raising the learner's awareness of his or her present state of knowledge; self-setting of feasible and worthwhile objectives; selection of materials; self-assessment" ( $(1.5)$, accompanied by the "ability to learn" as an explicit competence to be developed. Learners' awareness of and reflection on their language learning is supported by means of the European Language Portfolio (ELP), which consists of three parts: a language passport, which summarises experiences of learning and using other languages and a record of CEFR levels; a language biography, which offers a space to reflect on language learning and intercultural experiences, as well as to plan and record learning through a series of 'I can' statements; and a dossier, used to collect evidence of language learning and intercultural experiences. Use of the CEFR and ELP has been promoted through projects funded by the Council of Europe's European Centre for Modern Languages in Graz, Austria.

From an early stage, it was acknowledged that learner autonomy does not imply that learners are learning in isolation, but that it takes place within a sociocultural framework, involving interdependence. Oxford (2003), critiquing Benson's (1997) framework, added the sociocultural perspective to his three versions, arguing that we need to "systematically show how the important constructs of context, agency and motivation relate to different versions of autonomy" (p. 76). This has been significant in debates relating to the cultural appropriateness of autonomy in, for example, East Asian and Arab contexts (e.g. Palfreyman and Smith, 2003), or to the role of the learning advisor/counsellor in self-access learning (e.g. Mozzon-McPherson, 2001) and of the tutor in distance learning (White, 2003). The social nature of autonomy was in fact defined in the 
Bergen definition (Dam et al., 1990: 102-103), which emerged from the Third Nordic Workshop on Developing Autonomous Learning in the FL Classroom, a forum that continues to play an important role in relation to our understanding of learner autonomy:

Learner autonomy is characterized by a readiness to take charge of one's own learning in the service of one's needs and purposes. This entails a capacity and willingness to act independently and in cooperation with others, as a socially responsible person.

This focus on autonomy as a social-constructivist construct was reinforced by the development of research into its significance within classroom contexts. A significant contribution to our understanding of the nature and dynamics of learner autonomy in classrooms has been made by Leni Dam in Denmark. In her 1995 publication (Dam, 1995), she describes the principles, which underpin her work with secondary-aged English classes. These include involvement of learners in decision-making regarding the content of the lessons, using English (the target language) from the very beginning, and evaluating their learning by means of a reflective journal.

The work of Dam and others in developing autonomous learning in classrooms naturally led to a consideration of the teacher's role in developing autonomous learners. Dam was clear that learners needed support and guidance in developing both language competence and autonomy, and that teachers therefore had a major role to play, including challenging learners' decisions where necessary, whilst stimulating learners' naturalistic use of the target language. In the 2002 Singapore symposium of the AILA Scientific Commission on Learner Autonomy in Language Learning, the focus was on teachers, including their role and its implications for teacher development and teacher autonomy, as well as the relationships between learner and teacher autonomy.

This development necessitated a consideration of what teacher autonomy might mean. Little (1995) had been one of the first to draw parallels with learner autonomy:

Genuinely successful teachers have always been autonomous in the sense of having a strong sense of personal responsibility for their teaching, exercising via continuous reflection and analysis the highest degree of affective and cognitive control of the teaching process, and exploring the freedom that this confers. (Little, 1995:179)

Little (1995: 180) also suggested that "language teachers are more likely to succeed in promoting learner autonomy if their own education has encouraged them to be autonomous", introducing a focus on their autonomous learning experiences either as language learners or in their professional learning. An early collection of papers bringing together aspects of learner and teacher autonomy (Sinclair, McGrath and Lamb, 2000) contained a number of significant definitions of teacher autonomy, including self-directed professional development, freedom from control by others, and Smith's (2000) notion of teacher-learner autonomy. In this volume, Lamb (2000) expounded on a critical 
version of teacher (as well as learner) autonomy, which required teachers to reflect critically on issues of power and to engage themselves and their learners in action and self-empowerment:

As with pupils, teachers need to understand the constraints on their practice but, rather than feeling disempowered, they need to empower themselves by finding the spaces and opportunities for manoeuvre. (...) Critique (resistance) needs to be linked to transformation rather than resignation. (Lamb, 2000: 127)

In the publication which emerged from the AILA symposium in Singapore (Lamb and Reinders, 2008), Smith and Erdoğan (2008) went on to expand on Smith's (2000) notion of teacher and teacher-learner autonomy by identifying six dimensions, three relating to professional action (self-directed professional action itself as well as teachers' capacity for and their freedom from control over professional action) and three to professional development (self-directed professional development itself as well as teachers' capacity for and their freedom from control over professional development) (Smith and Erdoğan, 2008). Lamb and Reinders' (2008) publication, however, also explored the dynamic interrelationships between teacher and learner autonomy, which inevitably implied a negotiation of power relationships. This critical direction led to the development of a framework for a "pedagogy for autonomy" as part of a European project (EuroPAL), which introduced a common definition for both teacher autonomy and learner autonomy as aspects of a critical vision of education:

The competence to develop as a self-determined, socially responsible and critically aware participant in (and beyond) educational environments, within a vision of education as (inter)personal empowerment and social transformation. (Jiménez Raya, Lamb and Vieira, 2007)

The development of a 'pedagogy', which connected to practical aspects of learning and teaching within and outside the classroom, necessarily rejected liberal understandings of autonomy as 'freedom', but instead engaged actively with notions of power and constraints. In so doing, it built on the already wellestablished work on pedagogy for autonomy in Portugal, the Grupo de TrabalhoPedagogia para a Autonomia (Working Group - Pedagogy for Autonomy), which Flávia Vieira had established in 1997 at the University of Minho as a network of school teachers, teacher educators and academics, and which she described as " $a$ collective commitment to a collective struggle" (Vieira, 2009: 10).

The AILA symposium in 2002 also called for consideration of innovative, interpretivist methodological approaches to research, in order to be able to comprehend the phenomenon of learner and teacher autonomy in all its complexity. Though there had not been an exclusive focus on quantitative methodologies, research in the field had till that time largely adopted the positivist approaches of cognitive psychology in its studies of motivation, strategies and learner beliefs. In 2005, the symposium of the AILA Research Network (formerly Scientific Commission) on Learner Autonomy in Madison, 
Wisconsin, reflected this epistemological shift in its focus on learners' and teachers' voices. Employing a range of methodological approaches, including narratives, life histories and learner diaries, the papers in that symposium, many of which were later published in the journal Innovation in Language Learning and Teaching, directly addressed methodological questions about how to access and listen to voices, as well as how these voices might influence the pedagogical approaches adopted.

The new methodological approaches to exploring experiences of language learning (and teaching) found themselves re-connecting with new developments in motivation research that were beginning to explore issues of identity (Dörnyei and Ushioda, 2009), and in 2008, the AILA Research Network symposium in Essen, Germany, focused on the links between identity, motivation and autonomy (Murray, Gao and Lamb, 2011). The three constructs were described as organic, interrelated in complex ways, and consisting of "three noteworthy traits: they change over time, they depend on context and they are socially mediated" (Murray 2011, 248). As such, there was resonance with themes addressed since the 1980s, but in a qualitatively different way and with recognition of their complexities. The themes were built on in the 2011 AILA Research Network symposium in Beijing, which addressed the social dimensions of autonomy (Murray, 2014). The central questions being considered here were how social and contextual processes mediate language learner and teacher autonomy in particular settings, taking account of the increasingly interconnected world brought about by technological developments, including Web 2.0. With education policies across the globe and at all levels increasingly promoting learner autonomy, there was a need to explore the affordances for language learning within complex webs of entangled relationships and evershifting social identities.

\section{Work in progress}

The 2014 AILA Research Network symposium in Brisbane brought together five themes, which were considered to extend the traditions of research in learner autonomy as situated, social and critical. The first theme is taking a new look at sociocultural understandings of how autonomy is manifested in collaborative approaches to language teaching and learning and how autonomy contributes to social learning. The second theme is attempting to synthesise and theorise research into learner autonomy in the Web 2.0 Era. Technology has always been a significant focus in the field, mainly in formal learning contexts such as selfaccess and distance learning programmes. The rapid growth and globalization of digital media is now offering expanding and constantly changing opportunities for informal language learning and use, including digital tools such as mobile technologies and gaming.

Recent research into learner autonomy in different cultural contexts has begun to examine what the construct means in difficult circumstances, and how it can support effective learning (Kuchah and Smith, 2011). Two of the themes in the 2014 symposium are building on this work: the first is focusing on the developing world, where learner autonomy may have special relevance for 
learners, but where teaching and learning may be under-resourced; the second focuses on language teacher autonomy and social censure, exploring contexts, in which teachers are constrained by bureaucracy, surveillance and marketization.

The final theme is exploring the spatial dimension of autonomy, acknowledging that the spaces in which learners learn offer significant affordances for or constraints on learning. Spaces are interpreted broadly, as physical, virtual or even metaphorical, and can be formal or informal, private or public, personal or shared. Research in learner (and teacher) autonomy has been focusing on different contexts since its early days (self-access, classrooms, online and distance learning, for example), and more recently there has been recognition that, in some contexts, much learning (including teacher learning) occurs outside formal learning environments (e.g. Lamb, 2012). Current research is reconceptualising this research, drawing on ecological approaches to consider not only the impact of space on learning, but also ways in which spaces themselves are socially constructed, appropriated and transformed by learners into 'places', therefore offering insights into the dynamic interrelationships between learners, learning, and spaces.

\section{Problems and difficulties}

As a complex and dynamic construct, intertwined with other complex ideological, political, social, epistemological and pedagogical constructs such as beliefs, dependence/independence/interdependence, identity, knowledge, motivation, policy, situatedness, and SLA theory, there is no single approach to operationalizing learner autonomy in language learning. Nevertheless, there is a strong argument that learner autonomy as a construct is meaningless unless it can be related to practice. The IATEFL Learner Autonomy (previously Learner Independence) Special Interest Group has been organising regular international and regional events since 1986, many of which have focused on the relationship between theory, research and practice (e.g. Menegale, 2013). It has played a major role not only in advancing scholarship but also in supporting practising teachers, as evidenced through the titles of its e-publications and annual preconference events, such as 'Learner autonomy in action - across borders' in 2012 and 'Language learner autonomy: Getting started' in 2015. One on-going practical challenge involves a decision as to whether autonomy is a means or an end, which Kuchah and Smith (2011) have described as 'pedagogy for autonomy' or 'pedagogy as autonomy'; this will depend on the learning context. There is then the need to consider what is specific to learner autonomy in language learning; Little (2007) reminds us that the overall purpose of language learning is to develop proficiency in using the language, and that autonomy must then necessarily extend to autonomous use of the language. The classroom must therefore not neglect use of the language as a means of communication.

A further consideration is whether autonomy is acquired or innate. For Holec, the "ability to take charge of one's own learning [...] is not inborn but must be acquired either by 'natural' means or (as most often happens) by formal learning, i.e. in a systematic, deliberate way" (Holec, 1981, p. 3). On the other hand, Little (1991) draws on constructivism, perceiving autonomy as a capacity 
which already exists in the learner, but which can be developed further. This brings into question how to 'train' or 'develop' learners for increased autonomy, ranging from strategy training to reflection on deeper learning goals and motivations.

In order to afford opportunities for learner and teacher autonomy, there is a need to take stock of realities as well as ideals. According to Trebbi (2008), autonomy is not the same as freedom, if freedom is construed as absence of constraints. She argues that "human beings are never free from constraints simply by the fact that we are social beings", and goes on to claim that " $\mathrm{t}] \mathrm{he}$ question is not whether we are free or not, but rather whether we are victims of constraints or not" (p. 35). The point she is making is that consciousness and intentional awareness of constraints offer a starting point for critically examining such constraints and imagining a "concept, which is both informed by practice and which can help us understand practice" (p. 45). Defining constraints as external ("imposed from the outside") and internal (our "mental heritage [which] embraces phenomena such as attitudes, beliefs, insights") (p. 35), Trebbi argues that it is possible to turn constraints into opportunities through reflection on personal experiences.

The challenge then is for both learners and teachers to find the "spaces for manoeuvre", which will enable them to extend autonomy as far as is possible and appropriate within a particular context (Lamb, 2000). The EuroPAL framework (Jiménez Raya, Lamb and Vieira, 2007) offered a tool to enable educators to understand the constraints and affordances within their setting and to reflect critically on them. The setting is described as a landscape consisting of "a complex set of conditions in which teachers and learners operate", consisting of: a range of dominant ideological, political, economic, educational values, language teaching traditions, frameworks and guidelines, family and community expectations, institutional and curricular demands, and teacher education discourses and practices; teachers' own past experiences as learners and teachers, personal theories, linguistic backgrounds, and professional values; and learners' past learning experiences, personal theories, backgrounds and commitments to education. Over this landscape sweep (sometimes contradictory) forces, propelling or restricting the development of a pedagogy for autonomy; these forces can be theoretical, professional, practical, political, economic or technological, and may be local, national or global. The intention is to generate opportunities for transformation as follows:

By locating themselves in this landscape and understanding the conditions which obtain and the forces which sweep across it, teachers can consider critically their position within it and find ways of navigating through it, either removing the constraints or working round them, in any case exploiting their professional context in ways which will move them forward rather than hold them back. (pp. 19-20)

\section{Future directions}

One of the forces sweeping across the globe is the dominance of the discourse of assessment, primarily in a summative form, as an instrument of control. This has 
led to an increase in demand for measurement and testing of autonomy itself within those educational institutions where it is included as a learning outcome. Current research is engaging with the relationships between autonomy and assessment, though the most obvious connections are with formative assessment (e.g. Tassinari, 2012). Strong criticism of attempts to assess autonomy summatively has been made, arguing that it is multidimensional, not observable and developmental (Benson, 2010). Of course, problems with measuring autonomy also affect the ways in which it can be researched, and research funding usually comes with expectations of impact measurement. It is not yet clear how these paradoxes can be addressed, but research needs to continue to engage with them and to make clear and trustworthy arguments to act as a counterbalance to such external demands.

It is clear that development in the field of autonomy in language learning has expanded beyond the discrete spaces, which it occupied in its infancy in the 1970s. It has become a mainstream phenomenon, reaching all sectors of education and across the globe. It has moved beyond the self-access centre and even the classroom, to occupy a global space, which includes the digital and metaphorical (including curriculum space). The trajectory described above suggests that it is also entangled with ideological, political and moral webs on local, national and international levels. The current nascent work theorising space, place and autonomy will offer a valuable way of understanding the place of autonomy in the world, including the overlapping spaces of specific languagerelated research with broader educational, professional, technological, sociological and political scholarship. Research will need to continue to explore autonomy in different learning contexts, and increasingly in different cultural contexts as countries around the world shake off their traditional pedagogical approaches and embrace new political, even ideological, orientations.

Understanding these dynamic and interacting developments will require new conceptualisations, moving beyond the sociocultural to include the ecological and spatial.

It has long been argued that the vision of a pedagogy for autonomy is not specific to languages, but needs to comprehend the "transdisciplinary value of autonomy as an educational goal", to become "a whole-school project for learner and teacher development” (Jiménez Raya, Lamb and Vieira, 2007: 6-7). However, autonomy as a construct is not limited to education. Research in other disciplines, even outside the social sciences and humanities, is increasingly moving beyond its boundaries into new interdisciplinary spaces, and the construct of space itself has also moved beyond its origins in human geography to political, philosophical, educational and technological arenas. The expansion of research in the field of autonomy in language learning would benefit from doing the same. Whilst it is important not to lose sight of the aim of exploring autonomy in language learning (Little, 2007), there is much to be gained from insights in other fields. Just as research into language learning technology needs to embrace and critically explore the nature of learning and teaching not only in language laboratories and self access centres, but also more broadly distance learning, virtual learning environments, gaming sites, virtual reality spaces, and massive open online courses (MOOCS), so research into autonomy in language 
learning can learn from exploring what 'autonomy' means in other disciplines and other professions (architecture, design, management, social work etc).

The Council of Europe was instrumental in launching the new wave of research, policy and practice in autonomy in language learning, and it continues its work in this area. Similarly, it has a long-standing commitment to social justice, including valuing multilingualism and plurilingualism and promoting intercultural understanding. With the increase in global migration, ways need to be found to reassess which languages are learnt, where they are learnt and used, and how they are valorised. In various contexts, critically autonomous learners and teachers are finding the 'spaces for manoeuvre' in order to develop and protect inclusive linguistic spaces at formal educational levels. Exploring spatial dimensions can illuminate the physical, structural, social, curricular, virtual and affective spaces, which afford inclusive practices, enhancing opportunities for a wide range of languages to be learnt and used, for plurilingual identities to be nurtured, and for intercultural understanding to be fostered.

Beyond formal education, the construct of critical autonomy (Lamb, 2000) also enables us to identify ways in which plurilingual communities themselves produce spaces, in which they can ensure that their languages continue to be learnt and used, both in the home and beyond, such as in community-based informal schools, cultural gatherings and other everyday social spaces. Research into the interrelationships between personal and socio-cultural spaces for autonomy move us from the micro to the meso and beyond to the macro, perhaps returning us to a new, community-based conceptualisation of Plato's political autonomy.

The relationships between theory, research and practice are fundamental to developing work in the field of autonomy in language learning. Future developments will continue to acknowledge this and, in so doing, they will enable us to continue to enhance not only formal and informal language learning, but also intercultural understanding and dialogue and to sustain plurilingualism and multilingualism in the 21st century.

\section{References}

Benson, P. (1997). The philosophy and politics of learner autonomy. In P. Benson \& P. Voller (Eds.), Autonomy and independence in language learning (pp. 18-34). Harlow: Addison Wesley Longman.

Benson, P. (2010). Measuring autonomy: Should we put our ability to the test?. In A. Paran \& L. Sercu (Eds.), Testing the untestable in language and education (pp. 7797). Clevedon: Multilingual Matters.

Benson, P. (2011). Teaching and researching autonomy in language learning $\left(2^{\text {nd }}\right.$ Edition). Harlow: Longman. 
Council of Europe. (2001). Common European Framework of Reference for Languages: Learning, teaching, assessment. Cambridge: Cambridge University Press.

Dam, L. (1995). Learner autonomy 3: From theory to classroom practice. Dublin: Authentik.

Dam, L., Eriksson, R., Little, D., Miliander, J. \& Trebbi, T. (1990). Towards a definition of autonomy. In T. Trebbi (Ed.), Third Nordic Workshop on Developing Autonomous Learning in the FL Classroom (pp. 101-102). Bergen: University of Bergen. http:// www.warwick.ac.uk/go/dahla/archive/trebbi_1990.

Donmall, B.G. (Ed.). (1985). Language awareness, NCLE Reports and Papers 6. London: CILT.

Dörnyei, Z. \& Ushioda, E. (2009). Motivation, language identity and the L2 self. Bristol: Multilingual Matters.

Ellis, R. (2004). The definition \& measurement of L2 explicit knowledge. Language Learning, 54, 227-275.

Holec, H. (1981). Autonomy and foreign language learning. Oxford: Pergamon.

Jiménez Raya, M. \& Lamb, T.E. (2008). Manifestations of autonomy in the school curriculum. In M. Jiménez Raya \& T.E. Lamb (Eds.), Pedagogy for autonomy in modern languages education: Theory, practice, and teacher education (pp. 58-76). Dublin: Authentik.

Jiménez Raya, M., Lamb, T.E. \& Vieira, F. (2007). Pedagogy for autonomy in language education in Europe: A framework for learner and teacher development. Dublin: Authentik.

Kuchah K. \& Smith, R. (2011). Pedagogy of autonomy for difficult circumstances: from practice to principles. Innovation in Language Learning and Teaching, 5(2), 119140.

Lamb, T.E. (2000). Finding a voice: learner autonomy and teacher education in an urban context. In B. Sinclair, I. McGrath \& T. Lamb (Eds.), Learner autonomy, teacher autonomy: Future directions (118-127). Harlow: Pearson.

Lamb, T.E. (2012). Language associations and collaborative support: language teacher associations as empowering spaces for professional networks. Innovation in Language Learning and Teaching, 6(3), 287-308.

Lamb, T.E. \& Reinders, H. (Eds.). (2008). Learner and teacher autonomy: concepts, realities and responses. Amsterdam: John Benjamin. 
Little, D. (1991). Learner autonomy I: Definitions, issues and problems. Dublin: Authentik.

Little, D. (1995). Learning as dialogue: the dependence of learner autonomy on teacher autonomy. System, 23(2), 175-182.

Little, D. (2007). Language learner autonomy: Some fundamental considerations revisited. Innovation in Language Learning and Teaching, 1(1), 14-29.

Macaro, E. (2001). Learning strategies in foreign and second language classrooms. London: Continuum.

Marshall, J. D. (1996). Michel Foucault: Personal autonomy and education. Dordrecht: Kluwer Academic Publishers.

Menegale, M. (2013). (Ed.) Autonomy in language learning: Getting learners actively involved. Canterbury, UK: IATEFL.

Mozzon-McPherson M. (2001). Language advising: Towards a new discursive world. In M. Mozzon-McPherson \& R. Vismans (Eds.), Beyond language teaching towards language advising (pp. 7-22). London: CILT.

Murray, G. (2011). Identity, motivation and autonomy: Stretching our boundaries. In G. Murray, X. Gao, \& T.E. Lamb (Eds.), Identity, motivation and autonomy in language learning (pp. 247-262). Bristol: Multilingual Matters.

Murray, G. (ed) (2014). Social dimensions of autonomy in language learning. Basingstoke: Palgrave Macmillan.

Murray, G., Gao, X. \& Lamb, T. (Eds.). (2011). Identity, motivation and autonomy in language learning. Bristol: Multilingual Matters.

Naiman, N., Froehlich, M., Stern, H.H. \& Todesco, H. (1978). The good language learner. Toronto: Ontario Institute for Studies in Education.

Oxford, R.L. (2003). Toward a more systematic model of L2 learner autonomy. In D. Palfreyman \& R.C. Smith (Eds.), Learner autonomy across cultures: Language education perspectives (pp. 75-91). Basingstoke: Palgrave Macmillan.

Palfreyman, D., \& Smith, R.C. (Eds.). (2003). Learner autonomy across cultures: Language education perspectives. Basingstoke: Palgrave Macmillan.

Schmidt, R. (1994). Implicit learning and the cognitive unconscious: Of artificial grammars and SLA. Implicit and Explicit Learning of Languages, 22, 165-209.

Sinclair, B., McGrath, I. \& Lamb, T.E. (Eds.). (2000). Learner autonomy, teacher autonomy: Future directions. Harlow: Pearson. 
Smith. R. (2000). Starting with ourselves: Teacher-learner autonomy in language learning. In B. Sinclair, I. McGrath \& T. Lamb (Eds.), Learner autonomy, teacher autonomy: Future directions (pp. 89-99). Harlow: Pearson.

Smith, R. \& Erdoğan, S. (2008). Teacher-learner autonomy: Programme goals and student-teacher constructs. In T.E. Lamb \& H. Reinders (Eds.), Learner and teacher autonomy: Concepts, realities and responses (pp. 83-109). Amsterdam: John Benjamin.

Tassinari, M. G. (2012). Evaluating learner autonomy: A dynamic model with descriptors. SiSAL Journal, 3(1), 24-40.

Ushioda, E. (1996). Learner autonomy 5: the role of motivation. Dublin: Authentik.

Vieira, F. (2009). Struggling for autonomy in language education: Reflecting, acting and being. Frankfurt-am-Main: Peter Lang.

Wenden, A.L. (Ed.). (1999). Special issue on metacognitive knowledge and beliefs in language learning. System, 27.

White, C. (2003). Language learning in distance education. Cambridge: Cambridge University Press.

Zembylas, M. \& Lamb, T.E. (2008). Interrogating the notion of autonomy in education: tensions and possibilities. In M. Jiménez Raya \& T.E. Lamb (Eds.), Pedagogy for autonomy in modern languages education: Theory, practice, and teacher education (pp. 21-35). Dublin: Authentik. 